\title{
Private patios, a valuable hidden heritage for tourism development in the city of León, Nicaragua
}

\author{
A. Gómez Sal $^{1}$, A. González García ${ }^{1}$, C. Santovenia Pérez ${ }^{2}$ \\ \& P. Dávila Prado ${ }^{3}$ \\ ${ }^{1}$ Department of Ecology, University of Alcalá, Spain \\ ${ }^{2}$ School of Tourism, UNAN-León, Nicaragua \\ ${ }^{3}$ Department of Biology, UNAN-León, Nicaragua
}

\begin{abstract}
In traditional Latin-American cities, patios - private urban green spaces represent one of the most important urban green areas. Patios also contain some outstanding architectural and natural values and are important for human welfare. As they are private propriety, patios usually do not have a legal scheme of protection. In addition, there is a lack of scientific research, especially to document their importance from an ecological, cultural and historical point of view. This work analyzes the variety of patios in León (Nicaragua) with an emphasis on the naturalistic and landscape ecological components. The dual origin of León city - two explicit nuclei of colonial and indigenous origin resulted in an array of patio models, useful to investigate their variability as well as their different functions. Some of the conservation problems affecting patios are fragmentation, the increase of paved surfaces and the loss of knowledge on plant uses and management patterns. An ordered tourism use is proposed as both a development and a conservation tool. This initiative is currently being developed through a cooperation project promoted by the León municipality. This includes a scientific study of the patio components and values, a multifunctional categorization of patios and the application of the results to sustainable development goals. The experience could be extended to other Hispanic style cities in Latin-America and many tropical cities worldwide.

Keywords: urban ecology, urban greenspaces, patios, tropical cities, human induced diversity.
\end{abstract}




\section{Introduction}

Private urban green spaces, called "patios" in Latin American cities, are one of the most unknown green areas. In spite of this, patios frequently occupy an important surface of cities [1] and have a remarkable role in maintaining biodiversity. There is a long-established lack of scientific research in the study of these spaces in the context of urban ecology studies [2, 3], especially when dealing with tropical cities. In Central America, these spaces include a variety of models, which are based on diversity of the plant species, the type of architecture, the components and arrangement of the patio space and in the general management regimes.

In the city of León (Nicaragua), patios represent more than $85 \%$ of the overall urban green spaces surface [4]. The urban model is one of the reasons for this importance, with houses usually having only one storey - more rarely two - a regular disposition of streets forming the typical colonial square blocks and a relative scarcity of public parks. The present city of León, having survived for four centuries from the first Spanish settlement, has a large and well maintained historic centre that includes an important architectural heritage. Even though the historic monuments do not present serious conservation problems, the same thing does not apply to dwelling architecture - especially houses - that is increasingly under threat at present because of emerging economic development. Currently, civil buildings with heritage values are not under a global scheme of protection. The protection measures are limited to the facades of houses, but inside blocks, deep transformations are increasing and strongly affect the very special heritage of patios.

The work we present starts as a scientific project aiming to document the urban flora cultivated in patios, and the models of uses that can be recognized. This project is also the base for other objectives, intending to study the conservation state of patios in order to protect the identified heritage and also to act as a tool for sustainable development - based on tourism - for their owners.

\section{The study of plant biodiversity in the patios}

The ecological sampling of patios in León was carried out from 2001 to 2004 in 83 proprieties distributed in three previously differentiated urban sectors: historic centre (Hispanic colonial style buildings), indigenous neighbourhood (the Sutiaba quarter comes from a former indigenous settlement, close to the new city) and recent construction areas (from 20th century to nowadays). The results show a clear association between the floristic compositions of patios and the mentioned urban sectors [4] and allow the identification of a total of six typologies of patios according to plant diversity and uses (see Table 1 and Figure 1). Among them, two groups stand out because of their biodiversity. Species richness is also important in absolute terms in the whole study, with 293 species recorded in 96 sampled patios (61 randomly selected and 35 selected by a good state of repair or considered representative by experts). Mean species richness per patio was 26.21 , but there was a marked difference between patios as shown 
in Table 1. Biodiversity presents two relative peaks in the studied city, due to the existence of two clear schemes of patio - the colonial and indigenous models coinciding with the two former nuclei (León and Sutiaba) that constituted the roots of the present day settlement.

The functions that the proprietors give to the patios are also diverse, including scenic and habitat functions (especially in colonial patios), places to cook and perform other daily activities and places for self-sufficient agriculture practices (trees for fruit supply, livestock breeding, medicinal plants, etc).

Table 1: General characteristics of the different patio groups obtained. See González García and Gómez Sal [4] for further details.

\begin{tabular}{|c|c|c|c|c|c|}
\hline & $\begin{array}{c}\text { Mean } \\
\text { Species } \\
\text { richness }\end{array}$ & Frequent species & $\begin{array}{l}\text { Main plant } \\
\text { life form }\end{array}$ & Main uses & $\begin{array}{c}\text { Average } \\
\text { Surface } \\
\left(\mathrm{m}^{2}\right)\end{array}$ \\
\hline $\begin{array}{l}\text { Colonial } \\
\text { patios }\end{array}$ & 38.33 & $\begin{array}{c}\text { Dieffenbachia spp. } \\
\text { Nephrolepis biserrata } \\
\text { Begonia spp. } \\
\text { Rosa chinensis }\end{array}$ & Herb & Ornamental & 148.12 \\
\hline $\begin{array}{l}\text { Indigenous } \\
\text { patios }\end{array}$ & 60.80 & $\begin{array}{l}\text { Musa x paradisiaca } \\
\text { Psidium guajava } \\
\text { Citrus } x \text { limon } \\
\text { Capsicum annuum }\end{array}$ & Shrub / Tree & $\begin{array}{l}\text { Ornamental } \\
\text { / Food / } \\
\text { Shade }\end{array}$ & 875.31 \\
\hline $\begin{array}{l}\text { Fragmented } \\
\text { indigenous } \\
\text { patios }\end{array}$ & 19.61 & $\begin{array}{c}\text { Magifera indica } \\
\text { Psidium guajava } \\
\text { Citrus } x \text { aurantium } \\
\text { Citrus x limon }\end{array}$ & Shrub / Tree & $\begin{array}{c}\text { Food / } \\
\text { Shade / } \\
\text { Ornamental }\end{array}$ & 293.14 \\
\hline $\begin{array}{l}\text { Transitional } \\
\text { group } 1\end{array}$ & 32.36 & $\begin{array}{c}\text { Dieffenbachia spp. } \\
\text { Caladium bicolor } \\
\text { Neprholepis biserrata } \\
\text { Epipremnum aureum }\end{array}$ & Herb & Ornamental & 284.05 \\
\hline $\begin{array}{l}\text { Transitional } \\
\text { group } 2\end{array}$ & 14.00 & $\begin{array}{l}\text { Dieffenbachia spp. } \\
\text { Syngonium } \\
\text { podophyllum } \\
\text { Nephrolepis biserrata } \\
\text { Cordyline fruticosa }\end{array}$ & Herb & $\begin{array}{l}\text { Ornamental } \\
\text { / Food }\end{array}$ & 125.75 \\
\hline $\begin{array}{l}\text { Recent } \\
\text { patios }\end{array}$ & 4.80 & $\begin{array}{c}\text { Citrus } x \text { aurantium } \\
\text { Mangifera indica } \\
\text { Melicoccus bijugatus }\end{array}$ & Tree & $\begin{array}{l}\text { Food / } \\
\text { Shade }\end{array}$ & 107.62 \\
\hline
\end{tabular}

Two patio models (Figure 2) were found more relevant for the tourist proposals:

- Colonial patios: mainly located in the historical centre (Hispanic origin), they have a dominant herbaceous vegetation with sparse or absent trees and ornamental uses. The design is a central garden with four corridors that connect the patio with the different rooms. In the best conserved examples, there is a second backyard patio called "traspatio", where most daily activities are carried out.

- Indigenous patios: usually called "pationes" (large patios), have higher surfaces and plants were assigned to multiple uses, having a remarkable ethnobotanical importance. These spaces are mainly located behind the house and in connection to others adjacent large indigenous patios. The 
vegetation structure is maintained in different layers, evoking tropical dry forest architecture. In the most typical case they have live fences (special kind of succulents as Bromelia, Euphorbia, frequently mixed woody shrubs) that separate the proprieties.

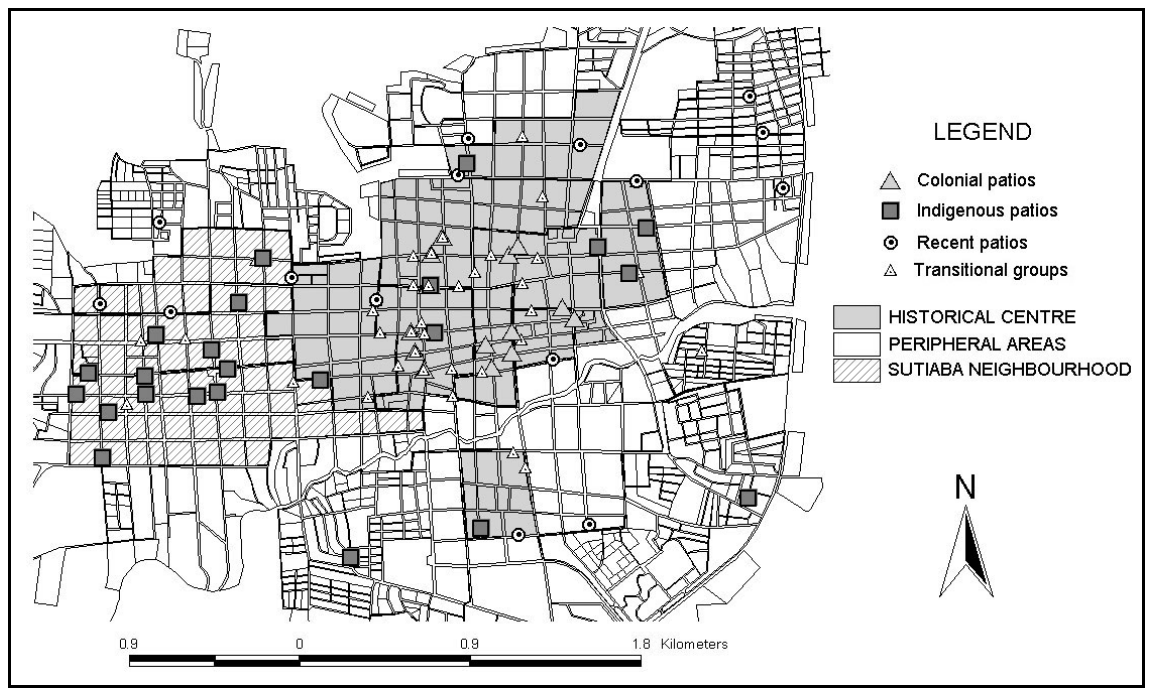

Figure 1: $\quad$ Map of León city showing the spatial distribution of the four patio models cited in Table 1. Different urban sectors (Historical centre, Sutiaba neighbourhood and Peripheral areas) were distinguished.

The habitats that patio groups create attract different kind of wild birds (Table 2). Birds in colonial patios are less diverse and use these spaces mainly for feeding, drinking (fountains are common) or resting places. Indigenous patios serve further functions, such as those of nesting and refuge. In general terms, doves (several species), robins (Turdus grayi) and grackles (Quiscalus mexicanus) are common species in all patio habitats and are very abundant.

\section{Threatened landscape}

The study also revealed a considerable problem of conservation and damage in traditional and non-traditional housings. There are three main problems affecting the documented values of patios:

- Successive fragmentation of the original housing: it is the main problem detected in León city [5]. Houses and patios are presently being divided as a consequence of inheritances and economical problems to maintain the complete structure.

- Other alteration processes are frequently associated with this, but can also occur in undivided housings. For instance the construction of new rooms in detriment of the patio surface; the increase of the paved surface of the patio reduces space for trees and ornamental plants. 
- Acculturation processes: affect the functionality of the original spaces and reduce biodiversity. The loss of the traditional patios management practices is noticeable in indigenous models, where the communities maintained systems connected with the natural surroundings. Nowadays, this has changed through the introduction of new ornamental species from nurseries, the influence of foreign fashions and designs in gardening and the loss of uses other than the ornamental (including the destruction of old live fences).

Figures 3 and 4 reflect the degree of alteration in some randomly selected patios, including the colonial and the indigenous archetypes. Most colonial patios present three corridors nowadays, but the original structure was formed by four corridors. In about $83 \%$ of the colonial houses there have been at least one division in the original structure.

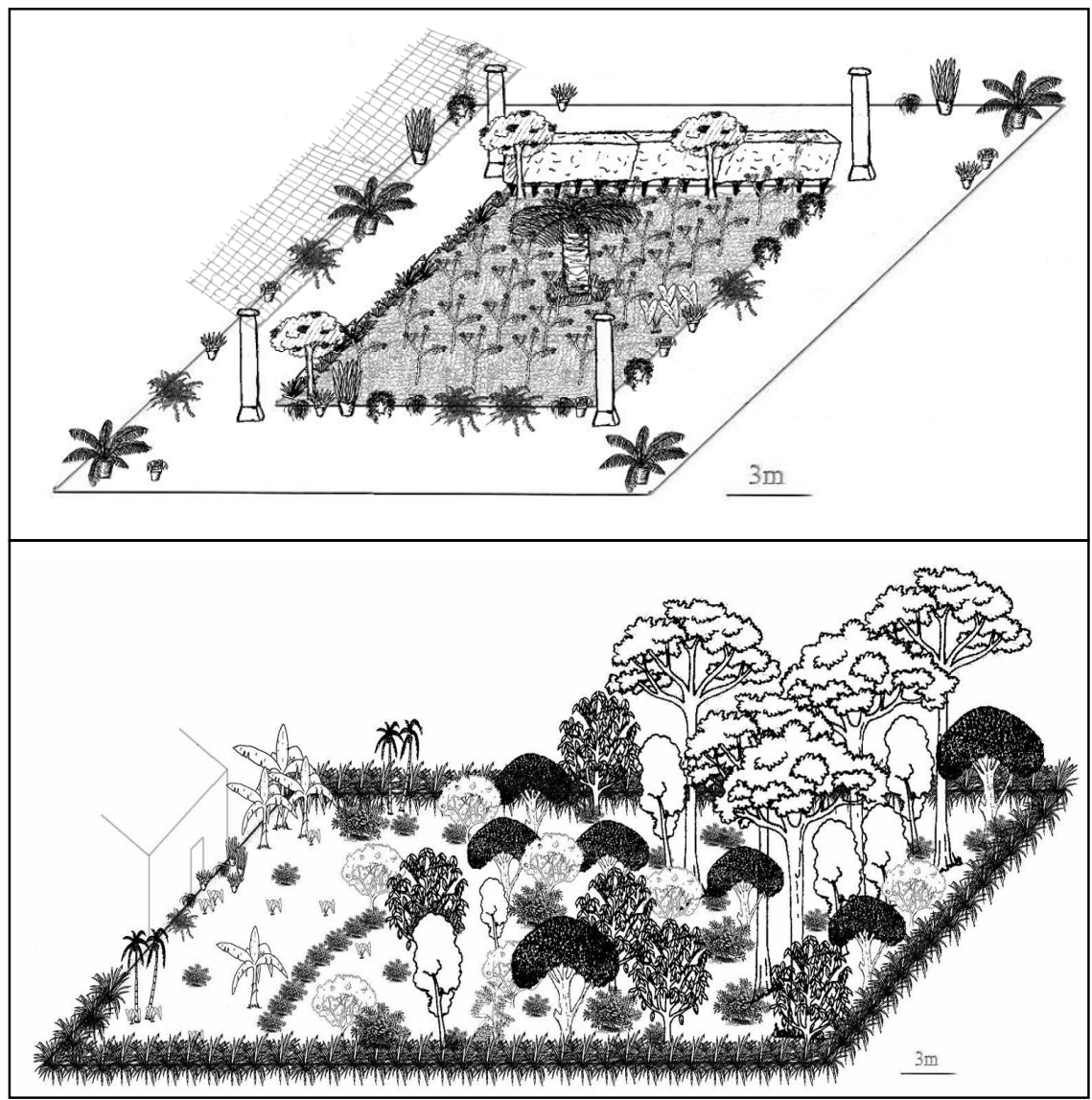

Figure 2: Representations of the two well preserved patio models, the colonial (top) and the indigenous (bottom). 
Table 2: Common birds in colonial and indigenous patios in the city of León (Nicaragua).

\begin{tabular}{|c|c|c|}
\hline & Colonial patios & Indigenous patios \\
\hline Doves (Columbidae) & $\begin{array}{l}\text { Zenaida macroura } \\
\text { Columbina talpacoti } \\
\text { Columbina inca } \\
\text { Columba livia }\end{array}$ & $\begin{array}{l}\text { Columbina talpacoti } \\
\text { Zenaida macroura } \\
\text { Leptotila verreauxi } \\
\text { Columbina passerina }\end{array}$ \\
\hline Parrots (Psittacidae) & & $\begin{array}{l}\text { Aratinga canicularis } \\
\text { Brotogeris jugularis }\end{array}$ \\
\hline Hummingbirds (Trochilidae) & Amazilia rutila & Amazilia rutila \\
\hline Tyrants (Tyrannidae) & Tyrannus melancholicus & $\begin{array}{l}\text { Myiozetetes similis } \\
\text { Pitangus sulphuratus } \\
\text { Tyrannus melancholicus }\end{array}$ \\
\hline Wrens (Trogloditidae) & & Campylorhynchus rufinucha \\
\hline Robins (Turdidae) & Turdus grayi & Turdus grayi \\
\hline Icterids (Icteridae) & $\begin{array}{l}\text { Quiscalus mexicanus } \\
\text { Icterus galbula }\end{array}$ & $\begin{array}{l}\text { Quiscalus mexicanus } \\
\text { Icterus pustulatus }\end{array}$ \\
\hline
\end{tabular}

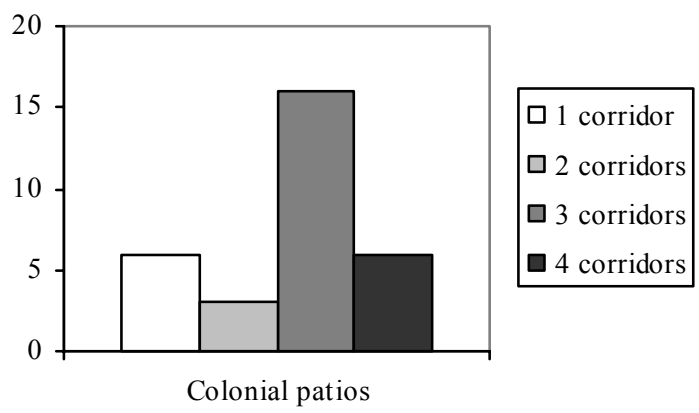

Figure 3: Number of preserved corridors in randomly selected colonial-style patios. The best preserved ones are patios with four corridors.

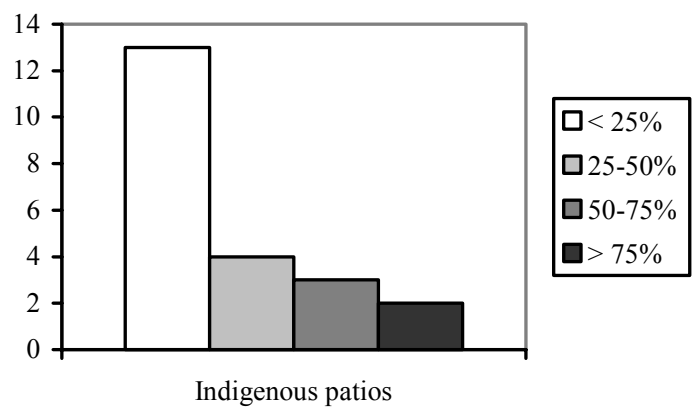

Figure 4: Number of indigenous patios affected by fragmentation. It is estimated that a mean surface of 1,667 square meters in original patios (six patios in each urban block, and approximately 10,000 square meters per block) Values represent the percentage of fragmentation considering this original surface. 
In indigenous patios, the degree of fragmentation is much higher. In general, patios preserve less than $25 \%$ of the original surface (Figure 4 ). This level of fragmentation with respect to the colonial ones may be caused by two factors: the very large original surface of indigenous patios and lower economic income of owners.

\section{Tourism as a tool for urban heritage conservation}

In developing countries there are serious problems for the conservation of natural and cultural heritage in the urban areas. The concern increases because of the demographic and economic dynamism of the present days, which can affect these fragile and strategic resources in irreversible ways. In the case of the private patios we found a hidden and not valuated patrimony with severe conservation problems. A contribution to solve the problem is to secure and enhance the benefits that patios bring to their owners through new initiatives and incentives to protect them. Tourism use in patios is one of the initiatives that can contribute to this double goal of heritage preservation and economic development. Urban ecotourism experiences are increasing worldwide and successfully contribute to the mentioned goals, as was reflected in the World Ecotourism Summit declaration [6].

The first proposal is to use a group of patios as an emblematic tourist attraction; some consequences are to diversify the touristic offer and to extend the stay of visitors in León city. A first step is to identify potential houses that should be included in a guided tour and to evaluate the state of conservation and the repairs if they are needed. Then, it should be necessary to have agreements and education actions with the owners engaged in the initiative. Those steps have already been considered in León, with the participation of some local authorities and groups (University, council, tourism office, and Historical Centre bureau). The School of Tourism of the University has made a market study that includes opinion polls about the interest of owners in the patio visits (see Table 3, [7]).

Table 3: Causes that justify the interest of visiting patios in León city (Adapted from Fornos and Santovenia [7]).

\begin{tabular}{|l|c|}
\hline Causes of interest & Responses \\
\hline Architecture & 61 \\
\hline History & 59 \\
\hline Environmental values & 24 \\
\hline Biological values & 11 \\
\hline Medicinal values & 3 \\
\hline Discover something new & 44 \\
\hline All the previous & 54 \\
\hline No response & 3 \\
\hline
\end{tabular}


Guided tours will include comments about natural, historical, architectural, aesthetic and habitational values. The application of an interpretative planning procedure is proposed, a technique to set up the tourism space with the aim of providing the visitor with suitable information about the patios attraction. This kind of planning will allow the visitor to understand the whole meaning of the houses, and how they contain valuable hidden ecological and architectural values.

At the moment, the initiative is looking for support and an elaborated project has been made. The efforts to engage owners in the project are being successful, with a good implication of both population and local authorities.

\section{Conclusions}

The present work emphasizes the importance of applying scientific knowledge to increasing of tourism initiatives based on not very explicit heritage values. A first step is to identify and document the new resources, and this is especially necessary in developing countries, which have a fragile and threatened cultural and natural heritage.

Private patios of some traditional cities of Latin America - like León, Nicaragua - represent a very unknown heritage, that stands out because of their plant biodiversity, the conspicuous and varied bird fauna, the richness of gardening designs, the very typical and climatically adapted architecture and their origin and functions. The importance of the nature conservation function of the León city patios comes also from the fact that they constitute near $85 \%$ of urban green spaces.

The kind of tourism based on private heritage, requires the keen implication of the local population as well as the development of effective actions to report to society the information about the importance of the newly documented values and initiatives (participation, organization, external and institutional support) to conserve and promote them.

\section{References}

[1] Smith, R.M., Gaston, K.J., Warren, P.H. \& Thompson, K., Urban domestic gardens (V): relationships between landcover composition, housing and landscape. Landscape Ecology, 20, pp. 235-253, 2005

[2] Gilbert, O.L., The ecology of urban habitats, Chapman \& Hall: London, pp. 23-24, 239-263, 1989.

[3] Thompson, K., Austin, K.C., Smith, R.M., Warren, P.H., Angold, P.G. \& Gaston, K.J., Urban domestic gardens I: putting small-scale plant diversity in context. Journal of Vegetation Science, 14, pp. 71-78, 2003.

[4] González García, A. \& Gómez Sal, A., The private urban greenspaces or "patios" as a key element in urban ecology of tropical Central America. Human Ecology (in press). 
[5] Oficina de Centro Histórico y Urbanismo, Plan especial de revitalización del centro de León: Estudio base tipológico-urbano-arquitectónico, Alcaldía de León, 2001.

[6] World Tourism Organization, Québec Declaration on Ecotourism, Québec, 2002.

[7] Fornos, V. \& Santovenia, C., Aprovechamiento turístico de los patios leoneses. Estudio de Mercado, Escuela de Turismo, UNAN-León, 2004. 